\title{
The Rise of K-Popper's Political Awareness in Twitter and What It Means for All of Us
}

\author{
Dani Fadillah ${ }^{1}$, Arif Ardy Wibowo ${ }^{2}$, Nunik Hariyanti ${ }^{3}$, Bai Long ${ }^{4}$, Luo Zhenglin ${ }^{5}$ \\ 1,2,3 University of Ahmad Dahlan \\ Jl. Kapas No.9, Semaki, Umbulharjo, Yogyakarta, Daerah Istimewa Yogyakarta 55166, Indonesia \\ ${ }^{4,5}$ Nanjing Normal University \\ No. 1 Wenyuan Road, Nanjing 210023, China \\ dani.fadillah@comm.uad.ac.id"*; arif.wibowo@comm.uad.ac.id²; nunik.hariyanti@comm.uad.ac.id³; \\ bailong880816@126.com ${ }^{4} ; 182875440 @ q q . c^{5}$ \\ *Corresponding author
}

\begin{abstract}
The Omnibus Law, which was passed on October 5, 2020, has discontented students and workers who protested on the streets. The ratification of the Omnibus Law has an effect on public opinion-raising activities, both those who support and who reject the ratification of the Omnibus Law, are crowded on Twitter social media. The active account of K-Poppers who took part became a line against the opinion of the Omnibus Law, so a question arises whether this is a phenomenon of the rise of political awareness of K-Poppers in Indonesia? This study analyzes the role of K-Poppers in socio-political movements in several countries globally, especially in Indonesia. The type of research used is a case study of the K-Poppers movement in the case of the ratification of the Omnibus Law as the subject in writing this paper. Collecting data using Social Network Analysis (SNA) and observing the activities of K-Poppers in Indonesia when parliament passed the controversial Omnibus Law. The results of this study indicate that Indonesian K-Poppers maximize their function as part of Indonesian citizens to express their political stance. They also showed their political involvement when creating hashtags, organizing other K-Pop crowds, and at the same time providing support to activists who rejected the Omnibus Law. Keywords: Social Media, K-Poppers, Soft Masculinity, Political Awareness
\end{abstract}

\section{Abstrak}

Omnibus Law yang disahkan pada 5 Oktober 2020 membuat ketidakpuasan para mahasiswa dan pekerja yang melakukan protes di jalanan. Pengesahan UU Omnibus Law berefek pada aktifitas penggalangan opini publik baik yang mendukung mapupun yang menolak pengesahan UU Omnibus Law ramai di media sosial Twitter. Aktifnya akun K-Poppers yang turut ambil bagian menjadi barisan melawan opini terhadap UU Omnibus Law, sehingga muncul sebuah pertanyaan apakah ini merupakan fenomena bangkitnya kesadaran politik para K-Poppers di Indonesia? Penelitian ini menganalisis peranan K-Poppers dalam gerakan sosial politik di beberapa negara secara global khususnya di Indonesia. Jenis penelitian yang digunakan adalah studi kasus gerakan K-K-Poppers kasus pengesahan Omnibus Law sebagai subject dalam menulis paper ini. Pengumpulkan data menggunakan Social Network Analysis (SNA) and mengobservasi aktifitas K-Poppers di Indonesia saat parlemen meloloskan UU Omnibus Law yang kontroversial. Hasil dari penelitian ini menunjukkan bahwa K-Poppers Indonesia memaksimalkan fungsinya sebagai bagian dari warga negara Indonesia untuk mengekspresikan sikap politik mereka. Mereka juga menunjukkan keterlibatan politiknya saat membuat tagar, mengorganisir massa K-Popper lainnya, dan sekaligus memberikan dukungan kepada para aktivis yang menolak Omnibus Law.

Kata kunci: Media Sosial; K-Poppers; Soft Masculinity; Kesadaran politik

\section{Introduction}

In early October 2020, thousands of students in several major cities in Indonesia took to the streets to protest against the Omnibus Law, which the Indonesian Parliament passed on October 5, 2020; students and labor activists were dissatisfied with the government and Parliament because the Law was still controversy. After all, it is considered not to benefit workers and only to benefit investors. Students also expressed disappointment with the Parliament's poor performance in fighting for land policies and labor welfare and wanted transparency in discussing a law. 


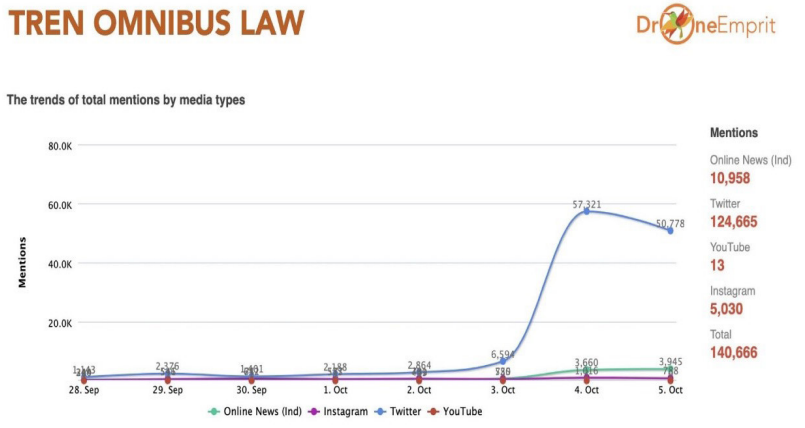

Figure 1 Omnibus Law talks surge after being passed by the Indonesian Parliament

Source: Fahmi (2020a)

Simultaneously, on Twitter, hashtags supporting the demonstration and regretting the passing of the controversial Omnibus Law continue to emerge; In Figure 1 shows a spike in rejections appear after Parliament passed the Omnibus Law.

In monitoring Twitter using the Social Network Analysis, surprising data was found about Indonesia's Twitter hashtag trend during 5-6 October when demonstrations began to break out in various regions. The hashtag \#MosiTidakPercaya has the highest volume of conversation, followed by \#BatalkanOmnibusLaw in second place. Interestingly, tweets in the top three come from the Generation Y cluster and K-Pop music fan accounts. This group dominates other hashtags carried by top public figure influencer@awkarin and K-pop lover account@beautifulyoongo. What is of concern here is that the @awkarin account's followers numbered 372,000 while the@beautifulyoongo version was only 133. However, the@beautifulyoongo performance received the most responses, up to 24,000 retweets,compared to@awkarin,onlyhalf.This fact is unique because the @awkarin account owner is a public figure, while the @beautifulyoongo account owner is just an ordinary idol fan.

The tweet from the @beautifulyoongo account was filled with video footage of an

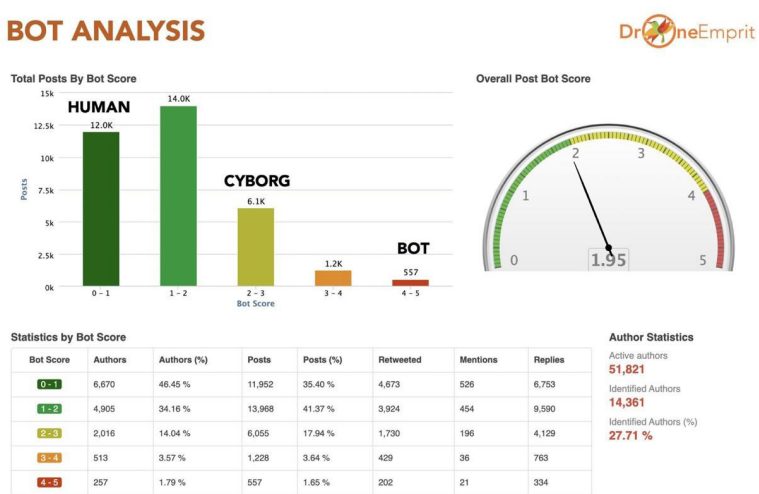

Figure 2 Organizational analysis of K-Poppers' accounts on social media

Source: Fahmi (2020a)

angry student demonstration. The account owner explained that the crowd was not K-pop concert fans but Indonesian students who demonstrated against the government for drafting laws that could potentially harm the people. Even though the tweets that K-pop fans and followers enlivened had less volume than the primary hashtag \#ReformasiDikorupsi, their numbers are still significant to show just how much the reach of K-pop fans in cyberspace has become.

Moreover, this phenomenon is interesting because the K-Poppers Twitter account that tweets its support for activists who rejected the Omnibus Law was indicated as an organic account, aka natural history, not BOT. Figure 2 illustrates the organization of the Twitter accounts belonging to K-Poppers.

The BOT analysis shows that more are detected as humans or approaching humans. Cyborg detection is relatively high because many K-Poppers, whose post types are not varied, only re-Tweet it. Besides that, the BOT score is also deficient, only 1.95 , very natural. That is why authors are very interested in conducting a study related to K-Poppers awareness on social media.

This phenomenon that occurs is something unique. In reality, K-Poppers worldwide show the fact that they can become social justice warriors, as in America and Indonesia. Research written by Zhang Qiang and Negus Keith entitled 
the East Asian Pop Music Idol Production and the Emergence of Data Fandom in China shows that K-Poppers is nothing more than a fandom gathering place that worships their idols (Zhang $\&$ Negus, 2020). Meanwhile, other studies from Meicheng Sun show that K-Poppers is the only creative business symbol developed by South Korea with a stream known as the Hallyu flow (Sun, 2020). Moreover, it is scarce to discuss K-Poppers from the side of social activists. Even studies from Ayu Saraswati entitled BTS Army's \#btsloveyourself: A Worldwide K-Pop Fandom Participatory Culture on Twitter emphasize that K-Poppers have a very high sense of sensitivity and compete with other fandoms (Saraswati, 2020). That is why this research was conducted, providing a new perspective on the K-Poppers phenomenon on social media that has domestic political concerns. The novelty of this research is to seek how K-Poppers are no different from young people who are active in student and student movements; K-Poppers are a nation's asset that can be utilized as much as possible by the will of the people.

There are two perspectives on social media. First, as a disseminator of information and second as a relationship builder. Facebook is a social media with a dual view, while Twitter has the first perspective. One of the reasons why Twitter is considered a spreader of information is that half of Twitter's trending topics make CNN headlines. Because Twitter can be a mouthpiece for conventional media coverage, many parties take advantage of it, especially the political world (Verweij, 2012).

Inspired by the Renaissance need for autonomy and freedom, Jürgen Habermas described the public sphere as a critical independence condition. In essence, the public domain was home to political discussions that were inclusive and rational (Rashem, 2018). A well-functioning public domain gives rise to the expression of a mediated and general public view. This criterion ultimately sees that public deliberation must take the form of the mechanism of rational-critical debate (Mwengenmeir, 2019). This basic conceptualization of contemplation as the rational-critical continuously debates in the public sphere's philosophy.

However, the foundation on which Habermas theorized and imagined the public sphere had changed drastically through a series of economic, social, and technological changes (Deane, 2005). For example, globalization and the information economy's growth have triggered the emergence of a new social structure, the network society (McKee, 2004). The traditional public sphere conception focused on the transition from feudalization through enlightenment with the emergence of mass culture (Habermas, 1989). The proliferation of new media modes has given rise to questions about the public sphere's vitality in an online age. Although the public sphere principle was extended to an online setting in an obvious way (Wheeler \& Iosifidis, 2016), others saw the need to amend the theory. The theoretical development of a revised type of public sphere, one based on the proliferation of information technology and revolving around the idea of networks, has given rise to the existence of an online networked society (Gimmler, 2001). From this focus, the idea of the networked public sphere (NPS) or the virtual public sphere was born. The NPS, taken from networked communications, is described as a "public discourse, political debate, and mobilization" space (Papacharissi, 2009). In the NPS, the distinction between public, private and political erodes as the room is "diffused, decentralized and distributed through the network itself" On the other hand, the virtual public domain claims that the Internet "will foster a debate that will promote the free exchange of ideas and views" (Papacharissi, 2009).

As mentioned by Antonio Gramsci in his understanding of popular culture, in this case, K-Pop culture can be related to the theory of hegemony (Kristiyono, 2018). The theory of hegemony explores how the dominant 
culture influences other groups, especially in constructing an identity or according to social norms. In other words, the public is unwilling to accept and believe whatever is conveyed by the dominant ideology (Purba \& Sholekha, 2019).

In presenting a rival ideology, K-Poppers use the same resources and strategies as those used by the dominant social group as the "owner" of the dominant ideology. For example, through mass media such as television or social media Twitter. This action was taken to oppose the dominant group's ideology and voice the views of groups silent so far (Morrisan, 2015).

Creating a new hegemony can only be achieved by changing awareness, mindset, understanding, and conception of society about the world and changing their norms of moral behavior. Gramsci referred to this movement as intellectual and moral revolution. Intellectuals have to carry it out. Gramsci believed that each class created one or more classes of intellectuals aware of their role, which is in the economy and the political and social spheres. Thus, class, the worker must also create his intellectuals to become a class hegemonic (Siswati, 2018).

Gramsci defines intellectuals as those who function as organizers in all levels of society, in production areas, politics or culture. Intellectuals are thinkers, writers, artists, organizers such as civil servants and political leaders, and experts involved in production activities, such as engineers, managers, and technicians.

This article will be using the Standpoint theory as an analytical tool. Standpoint theory is based on an understanding of something and concludes what you see. Standpoint theorists make the case that these insights expanded to defined social locations such as gender or race (Wylie \& Sismondo, 2015). To uses standpoint theory as an analytical tool, this article examines explanations of K-Poppers with on their action to raise awareness on social media about the Omnibus Law. By the theoretical assumptions. The authors hope to show the potential contributions and limitations of standpoint theory as an analytical tool and as a method to engage pressing political issues.

\section{Research Methods}

With the development of Web 2.0 architecture technology, there have been many emerging applications that are more interactive between the user and the application and support the development of applications that support interaction between users. Applications that are very much developed are social media applications. With this application, it is possible to analyze the various aspects of the formed social network. Twitter is one of the most popular online social media applications, ranking the 2nd largest globally (Haffner, 2020). It will be tough to find forms of social networks with many users and analyze them with a manual approach. Relationships or relationships between individuals that exist in the Twitter application can be very complex. Based on the reviews that Haffner has expressed in their research on the interaction of accounts on Twitter with actual social interactions, it is stated that the exact number of friends is only about $13 \%$ of the number of followers or followers declared on Twitter.

However, in this study, authors still assume that the definition of "friend" in the network on Twitter is if an account follows other people's reports and vice versa. So that between the two versions, two nodes will be formed with two directed edges pointing at each other. We will filter from the list of accounts followed by the list of stores that follow them (followers) with this assumption.

This paper includes the research results and discussion of the qualitative descriptive research. In this matter, the researcher collected various information about the research subject and object (Maxwell \& Reybold, 2015). The subject of this research is K-Poppers-s activity in social media. At the same time, the object of this research is how the Social Network Analysis 
(SNA) analyzes what they do in their movement to improve further its performance in supporting a social issue. As gathering the information, the researcher conducted The author collects data on disseminating information on social media using an application that can draw information on information circulation maps on social media, especially Twitter; in this case, the author collaborates with the drone emprit.

There are two kinds of ways to represent existing information, namely by using graphs and matrices. Of the many types of charts that exist, network analysis uses a kind of graph containing nodes or points to represent actors and edges or lines to represent relationships or relations, called "socio-grams." There are two ways to describe a relationship in a graph symbolized by using edges or lines: directed graph and bonded-telegraph or straightforward. The bonded-tie or straightforward graph is a simple graph that connects a pair of actors who have a relationship; only edges or lines are used without using arrows. A directed graph is a graph that can show relations more clearly because arrows represent relations symbolized by edges or lines (Milani et al., 2020). In this study, an undirected graph will be used to describe the relationship between individuals.

Since its introduction in 1930 by Jacob Levy Moreno, SNA has progressed very rapidly. However, several components or software are needed so that all the learning social network analysis applications can be carried out correctly. Previously, it must be understood that the network is an association of people called actors or nodes connected by links or ties (Butts, 2008). The purpose of the actors or nodes is a group of people or individuals involved in a network or network and connections or associations.

In addition, actors or nodes can also be organizations or departments, depending on how the analysis will be carried out. Relationships or ties are also not always the same, all purposes, goals, and needs. For example, in the form of suggestions, conveying ideas, assignments, skills, procedures, and emotional closeness such as friendship, kinship, and even love. In this case, Social Network Analysis has a particular opinion if a relationship between actors or nodes is essential. Social Network Analysis focuses on finding out whom the actors or nodes are involved with each other and how a relationship can occur (Can \& Alatas, 2019).

For example, actors or nodes have a relationship, the strength of the relationship, and the form of the relationship. For instance, whether the relationship is in one direction only or vice versa. The next thing that needs to be known is how the relationship gets the facilities, media or means used. It can be continued until several other software or components and applications, such as who has the most relationships or ties and the isolated party in the network or network. It continues the gap or distance, and the length and range between each actor and node are the bottlenecks, who the leading player or key planner is. Nowadays, social network analysis can be done conventionally and using special software on the computer. However, even the availability of its components is too complete, for example, geometric computations, mathematical structures, semantic data, differential equations, and others.

\section{Results of Research and Discussion The rise of K-Poppers' political awareness around the world}

This movement of K-Poppers' moral and political support did not only happen in Indonesia. Previously, the K-pop fan community in the United States participated in the Black Lives Matter (BLM) anti-racism movement and dared to fight against police violence after the death of a black man named George Floyd in the hands of the Minneapolis police at the end of May. K-poppers' action on social media began by attacking a digital application called iWatch belonging to the Dallas Police Department in Texas. Simultaneously, as the demonstration 
broke out, the Dallas police officer asked the public to help upload photos or recordings of "illegal activity during the protests". However, it was reported in The Dallas Morning News, a few hours later, the iWatch application crashed because it was flooded by Fancam or K-pop star stage performances recorded by concert audiences. An invitation from a K-pop fan account, @7soulsmap, was to confuse the application with uploads of K-pop idols to protect the BLM demonstrators' identities. Not long after, as reported by Newsweek, K-pop video attacks also flooded portals belonging to the Philadelphia Fire Department and the Kirkland and Grand Rapids police, who initially, like the Dallas police, asked for public participation report criminal acts committed by demonstrators.

Also, The Verge observes how the K-poploving community has targeted the hashtag \#MAGA (President Donald J. Trump's campaign slogan for "Make America Great Again") and the hashtag defending the police force \#BlueLivesMatter. This attack was launched as Trump threatened to deploy the military to disperse the BLM demonstrations. The posts with the right-bow tag ended up being filled with K-pop threats and memes intent on mocking these movements. The BBC also noted K-poppers' accounts that enlivened the hashtags \#AllLivesMatter and \#WhiteLivesMatter with threats. As a result, even though these hashtags have become popular on Twitter and Instagram, the content does not contain messages supporting the police apparatus, the MAGA movement, or other racist and conservative views.

As one of the boy bands whose threats were spread by fans during the anti-racism protests, Bangtan Boys, also known as BTS, also expressed support for the BLM movement through an official Twitter account with nearly 27 million followers. Shortly after the tweet was uploaded, entertainment media Variety announced that BTS and the Big Hit Entertainment management team had donated 1 million USD (approximately
14 billion rupiahs) for the BLM movement. This public statement also moved millions of BTS fans known as ARMY (Adorable Representative M.C for Youth) to raise donations. As reported by The New York Times, a fan club named One in an ARMY managed to raise more than 1 million USD in less than two days since the news of the donation by BTS. They also mobilized other BTS fans to enliven the hashtag \#MatchAMillion on social media to achieve the donation target immediately.

Late this June, The New York Times reported on claims from K-pop fans and teenage TikTok users who booked free tickets for the Trump campaign but did not attend. The move was quickly set on the network of K-pop fans and Tiktok users after the Trump campaign team's official account announced that it was opening up for free campaign ticket registrations online. CNN also found video uploads that were watched more than 300,000 times, especially inviting BTS fans to participate in pranks on the Trump campaign. When the campaign finally kicked off in Tulsa, Oklahoma, on June 20, it proved that the show was not that crowded. The stadium's 19,000,000-seat capacity was not met, although Trump acknowledged 1 million confirmed spectators. While it is difficult to determine how significant the role of K-poppers and young TikTok players will be in the prank campaign, it must be admitted that they have contributed to a certain degree in the constellation of modern American politics.

The activism of K-pop fans has previously been recorded in other countries. In 2018, K-poppers' accounts also enlivened the hashtag \#WeWantJustice as support for a student demonstration in Bangladesh demanding safety on the streets after two students' death due to traffic accidents. Also, Newsweek reported that the Chilean government once accused K-poppers of being the source of anti-police comments on social media when in October 2019, there was a student protest demanding a resolution to 


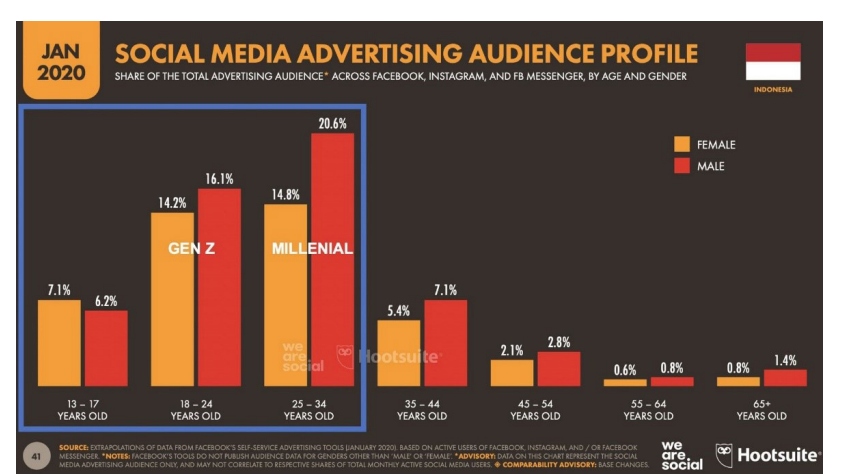

Figure 3 Comparison of inter-generational internet users in Indonesia

Source: Kemp (2020)

the issue of social class and wage inequality in Chile. Earlier this year, The Independent covered a donation of breakfast packages from the BTS fan community for Magic Breakfast, a charity in London that distributes nutritious breakfasts to disadvantaged children in Great Britain. In South Korea, Reuters reports that BTS militant fans are donating to prevent COVID-19.

\section{Fan Activism}

As seen in various countries, the K-pop music lover community shows high enthusiasm and solidarity towards social and political issues. Most started with online advocacy, and some made this through donations. This mobilization in the fan community is what Henry Jenkins calls "fan activism," a civic engagement and political participation that grows from within the fan culture itself. In general, according to Jenkins, these actions are a response to the interests shared by fans, which are carried out through the existing infrastructure of practices and relationships between lovers. They are framed with metaphors drawn from participatory culture and popular culture.

Based on Jenkins' view, the recent strengthening of K-poppers' activism is inseparable from the fanaticism in the K-pop fan community. The ease of digital access mainly supports this to consume, distribute, and reproduce popular culture. In Indonesia itself, the militancy of K-pop lovers in Indonesia is shown by collecting official souvenirs, watching concerts abroad, and increasing idol groups' popularity by increasing the views of their music videos.

K-poppers, which are dominated by young people, in Figure 3, is shown as the majority of social media users in Indonesia, including the tech-savvy generation who are fast mastering various techniques to popularize the latest news about their idols in online communication networks. People often label this group as an annoying group. People often label this group as an annoying group. Because they adore their idol, being consumptive in collecting expensive merchandise and Korean lifestyles. However, when this spirit is mobilized to support humanitarian action and political movements, the impact is massive, especially on social media.

In Figure 3, we can see that on October 3, 2020, the tweet regarding the Omnibus Law was still not widely discussed. Then entering October 4, 2020, when the Indonesian Parliament discussed the Omnibus Law, K-Poppers began moving on social media until the hashtag \#omnibuslaw trended internationally on October 5, 2020. The hashtag would not be trending without an online mass organization by K-Poppers. This trending hashtag then influenced the online and virtual world when the omnibus law was passed to this day.

Based on standpoint theory, this change in behavior from K-Poppers manifests their understanding that the socio-political atmosphere in Indonesia is uncertain. K-Poppers saw that the Omnibus Law phenomenon in Indonesia needed attention from the public, so a movement was made on Twitter which later became a trending topic. The K-Poppers suddenly get public support even though they have been labeled as a disturbing group. With the movement of K-Poppers, the public is becoming more and more aware of the importance of the Omnibus Law, although, in the end, it is still legalized as law. 
ONLINE NEWS TREND

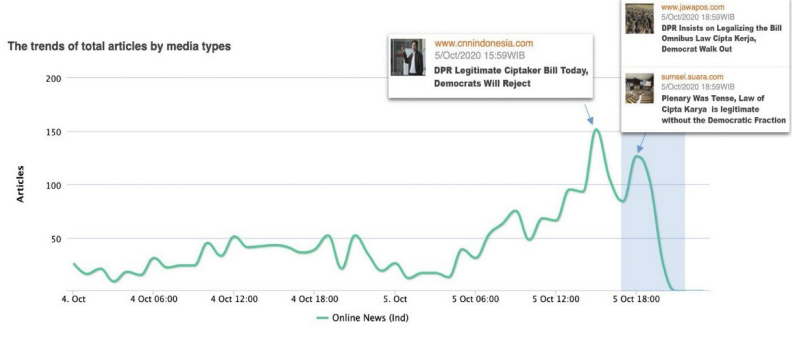

Figure 4 News spike of rejection of the Omnibus Law by the mass media in Indonesia

Source: Fahmi (2020b)

Based on SNA's observation in Figure 4, it shows that the tweets made by Indonesian K-Poppers aimed at providing moral support for student and labor union activists made news about the ratification of the Omnibus law by the government and Parliament into the spotlight of national information on that day. Whereas in Figure 4, it can be seen how, on October 5, all the news about the rejection of the Omnibus Law has increased rapidly, especially on Twitter.

The results can be seen in Figure 5, based on SNA's monitoring of a list of rejections of the Omnibus Law becoming a giant snowball that drowns government influencers' tweets.

The surge in the news of the rejection of the Omnibus Law in Figure 6 has a timeline directly proportional to Tweets' increase to reject the Omnibus Law by K-Poppers on social media.

This phenomenon that occurred at the beginning of October 2020 was not the first time. At the end of 2019, the Indonesian K-Poppers had enlivened the virtual world with the hashtag \#ReformasiDikorupsi due to the passage of laws related to Corruption Eradication in Indonesia and several other controversial laws. In midJune 2020, K-pop lovers in Indonesia also voiced support for an Indonesian stand-up comedian named Bintang Emon. After the comedian commented humorously about irregularities

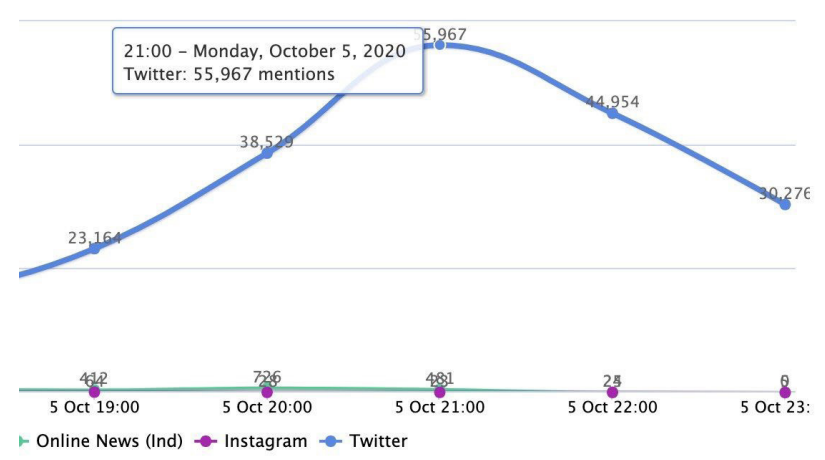

Figure 5 The peak of the conversation that rejected the Omnibus Law on October 5, 2020

Source: Fahmi (2020a)

in Indonesia's legal cases, Bintang Emon accused influencers and government buzzers of being drug users. However, the allegations were refuted by the results of the lab tests. The tweet that then appeared on Twitter showed the uploader's awareness that K-pop lovers' spirit of militancy could be used to provide moral support for activists, not only worship their idols.

Here, K-Poppers Indonesia maximizes its function as part of Indonesian citizens to express its political stance, which other international K-Poppers supporters support as part of world citizens' cosmopolitanism. At this point, their love for K-Pop fans does not dampen their love for Indonesia. This phenomenon shows that K-Poppers' fanaticism shows similarities with other music groups, especially masculine ones such as Rock, Metal, Punk, and others. Although they are very pop and seem anti-political, they exhibit actual political attitudes beyond the standard assumptions of many. They organize an online community by translating issues in Indonesia to K-Poppers fans worldwide to become part of the problems they voice. This condition allows this issue hashtag to continue to perch in cyberspace. Whereas their political awareness is formed, and social media is truly a forum for their community to continue speaking to declare their political position to humanity. 
SNA OMNIBUS LAW (17:00- 22:00)

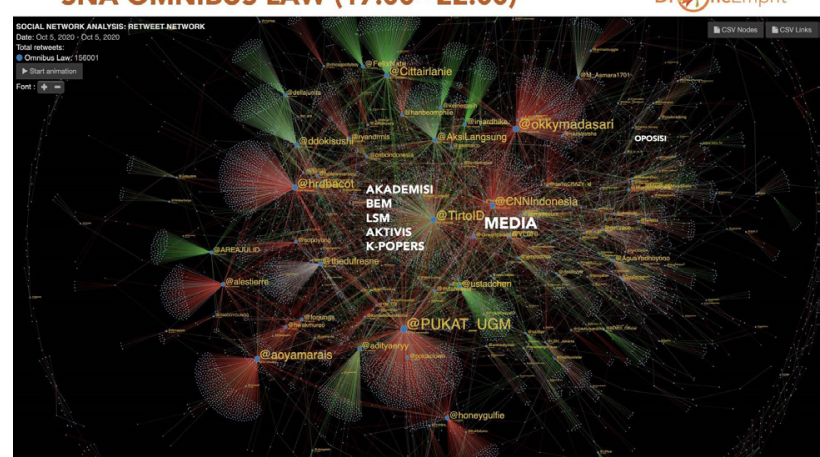

Figure 6 The outbreak of rejection of the Omnibus Law on Social Media on October 5, 2020

Source: Fahmi (2020a)

\section{Conclusion}

Not a few people mock K-Pop fans. Apart from being excessive and having poor music taste, K-Poppers are considered too fanatical about girl bands that rely solely on dance. A boy band, which has soft masculinity, is considered too feminine for a band. Not only that, their rowdy appearance made other music fans think it was not a music group but just a dancing festival that relied on their lip-sync skill. However, behind this slanted assumption, K-Poppers show the face of political involvement wherever they are. The ability to create hashtags, organize masses of other K-Poppers fans worldwide, their relatively young age segment, and digital literacy to access information related to their K-Pop fans make their presence indispensable as boybands or girls band fans. In online resistance campaigns, it is their presence that best determines how the fight is carried out.

When K-pop music becomes a global phenomenon, the politicization of K-pop by its fans becomes inevitable, especially among young people who are cultivating a sense of sensitivity and criticism of social and political issues around them. K-pop fans come from a young group that is socially progressive, openminded, and able to interact online. K-pop fans are willing to learn about new cultures to explore an interest in popular culture products.
With such a character, accompanied by a high level of dedication to K-pop, it is understandable why K-poppers are so passionate about defending the anti-oppression movement.

Although K-pop music's message does not have to be overtly political, it is often about empowerment and self-confidence. Uniquely, the politicization of K-pop that was animated by K-Pop fans in Indonesia, the United States, and other countries seemed very spontaneous and fast. Suppose American K-Poppers has been actively campaigning for Black Life Matter on social media. Even before the boy band BTS has given their official support, in Indonesia, K-Poppers are, in fact, directly giving their support to activists who reject the Omnibus Law, even though the idols they adore do not understand the problem at all. What happened in Indonesia shows that fans are now more interested in seeing mass movements that emerge from within their community, and they can make it happen quickly. At the same time, they still think that idols even must support specific goals or movements.

\section{Acknowledgements}

The authors thanks to Universitas Ahmad Dahlan and Nanjing Normal University for supporting this research. The author also thanks to the drone Emprit, who has been willing to provide data to the author during this research.

\section{References}

Ayu Saraswati, L., \& . N. (2020). BTS ARMY'S \#BTSLOVEYOURSELF: A Worldwide K-Pop Fandom Participatory Culture on Twitter. KnE Social Sciences. https://doi.org/10.18502/kss.v4i14.7899 Barr, S. (2020). James Corden thanks BTS fans for donating thousands towards children's charity. The Independent. https://www. independent.co.uk/life-style/james-cordenbts-army-charity-children-magic-breakfastthousands-late-late-show-a9307721.html 
Butts, C. T. (2008). Social Network Analysis with sna. Journal of Statistical Software, 24(6). https://doi.org/10.18637/jss.v024.i06

Can, U., \& Alatas, B. (2019). A new direction in social network analysis: Online social network analysis problems and applications. Physica A: Statistical Mechanics and Its Applications, 535, 122372. https:// doi.org/10.1016/j.physa.2019.122372

Deane, J. (2005). Media, democracy and the public sphere. In Media and Glocal Change: Rethinking Communication for Development (p. 178). Consejo Latinoamericano de Ciencias Sociales. Fahmi, I. (2020a). Drone Emprit Academic: Software for social media monitoring and analytics. Drone Emprit. http://dea.uii.ac.id

Fahmi, I. (2020b). Onimbus Law Peta Aspirasi Publik di Media Sosial. Drone Emprit. https://twitter.com/ismailfahmi/ s t a tu s / 1313062082800091136

Gimmler, A. (2001). Deliberative democracy, the public sphere and the internet. Philosophy \& Social Criticism, 27(4). https://journals.sagepub.com/doi/s/10.1177 $/ 019145370102700402$ ? journalCode $=$ pscb

Habermas, J. (1989). The Structural Transformation of the Public Sphere. Polity.

Haffner, M. (2020). Twitter. In Geographies of the Internet. https:// doi.org/10.4324/9780367817534-20

Jenkins, H. (2011). "Cultural acupuncture": Fan activism and the Harry Potter Alliance. Transformative Works and Cultures, 10. https://doi.org/10.3983/twc.2012.0305

Kemp, S. (2020). Digital 2020: 3.8 Billion People Use Social Media. We Are Social. https:// wearesocial.com/blog/2020/01/digital2020-3-8-billion-people-use-social-media

Kristiyono, J. (2018). Digital Activism: Counter Hegemony Komunitas Seni Digital Biennale Jawa Timur. Universitas Airlangga. Lemieux, M. (2019). Chilean Government Blames K-Pop For Recent Protests.
Newsweek. https://www.newsweek. com/chilean-government-blamesk-pop-recent-protests-1479151 Maxwell, J. A., \& Reybold, L. E. (2015). Qualitative Research. In International Encyclopedia of the Social \& Behavioral Sciences: Second Edition. https://doi. org/10.1016/B978-0-08-097086-8.10558-6

McKee, A. (2004). The Public Sphere: An Introduction. Cambridge University Press. Milani, E., Weitkamp, E., \& Webb, P. (2020). The Visual Vaccine Debate on Twitter: A Social Network Analysis. Media and Communication, 8(2), 364-375. https://doi.org/10.17645/mac.v8i2.2847 Morrisan. (2015). Teori Komunikasi individu hingga massa. Prenadamedia Group. Mwengenmeir. (2019). Habermas' Public Sphere. Media Studies 101. https:// opentextbc.ca/mediastudies $101 /$ chapter/habermas-public-sphere/

O'Sullivan, D. (2020). TikTok users are trying to troll Trump's campaign by reserving tickets for Tulsa rally they'll never use. CNN. https://edition.cnn.com/2020/06/16/politics/ tiktok-trump-tulsa-rally-trnd/index.html Papacharissi, Z. (2009). The Virtual Sphere 2.0: The Internet, the Public Sphere and beyond. In Handbook of Internet Politics.

Park, M. (2020). BTS fans keep fervor alive amid coronavirus outbreak. Reuters. https:// br.reuters.com/article/idUSKBN2150C8

Purba,R., \& Sholekha, N.(2019). Kesetiakawanan Fans K-Pop di Era Digital. Media Informasi Penelitian Kesejahteraan Sosial, 43(2), 2019.

Rashem Rashem. (2018). Public Sphere and the Power of Mass Media. The Circular. http://thecircular.org/publicsphere-and-the-power-of-mass-media/ Sharma, P. (2020). Angry Students in Bangladesh Take to Social Media to Share Horrific Instances of Violence. South Asia Journal. http://southasiajournal.net/angry-studentsin-bangladesh-take-to-social-media-toshare-horrific-instances-of-violence/ 
Siswati, E. (2018). Anatomi Teori Hegemoni Antonio Gramsci. Translitera : Jurnal Kajian Komunikasi Dan Studi Media, 5(1), 11-33. https://doi.org/10.35457/translitera.v5i1.355

Sun, M. (2020). K-pop fan labor and an alternative creative industry: A case study of GOT7 Chinese fans. Global Media and China, 5(4), 389-406. https:// doi.org/10.1177/2059436420954588

Verweij, P. (2012). Twitter Links Between Politicians And Journalists. Journalism Practice, 6(5-6), 680-691. https://doi. org/10.1080/17512786.2012.667272

Vincent, J. (2020). K-pop stans are flooding right-wing hashtags like \#BlueLivesMatter and \#MAGA. The Verge. https://www. theverge.com/2020/6/3/21278950/kpop-stans-social-media-floodinghashtags-bluelivesmatter-maga
Wheeler, M., \& Iosifidis, P. (2016). Social Media, Public Sphere and Democracy. In Public Spheres and Mediated Social Networks in the Western Context and Beyond. Palgrave Macmillan. https:// www.researchgate.net/publication/303097866 Social_Media_Public_Sphere_and_Democracy Wylie, A., \& Sismondo, S. (2015). Standpoint Theory, in Science. In International Encyclopedia of the Social \& Behavioral Sciences (pp. 324-330). Elsevier. https://doi. org/10.1016/B978-0-08-097086-8.85032-1

Zaveri, M. (2020). BTS Fans Say They've Raised \$1 Million for Black Lives Matter Groups. The New York Times. https:// www.nytimes.com/2020/06/08/arts/ music/bts-donate-black-lives-matter.html Zhang, Q., \& Negus, K. (2020). East Asian pop music idol production and the emergence of data fandom in China. International Journal of Cultural Studies, 23(4), 493-511. https://doi.org/10.1177/1367877920904064 